\title{
Zdolność skargowa gminy w postępowaniu przed Trybunatem Konstytucyjnym
}

\author{
Anna Chmielarz-Grochal \\ Dr, Uniwersytet Łódzki, Wydział Prawa i Administracji, \\ Katedra Prawa Konstytucyjnego \\ http://dx.doi.org/10.18778/8088-114-3.07
}

\section{Wprowadzenie}

Problem legitymacji gminy do złożenia skargi konstytucyjnej, mimo utrwalonej linii orzeczniczej Trybunału Konstytucyjnego, nie traci na aktualności z uwagi na wciąż podejmowane przez gminy inicjatywy „skargowe”. Trybunał jednak konsekwentnie prezentuje pogląd prawny, że jednostki samorządu terytorialnego nie mają legitymacji do wniesienia skargi konstytucyjnej¹. Decyduje o tym kilka czynników. Po pierwsze, jednostki samorządu terytorialnego - jako podmioty realizujące (stosownie do art. 16 ust. 2 i 163 Konstytucji) zadania władzy publicznej - ze swej natury nie mogą być adresatem uprawnień wynikających

1 Zob. w szczególności postanowienie TK z 22 maja 2007 r., SK 70/05, OTK ZU 2007, nr 6, seria A, poz. 60; zob. także postanowienia TK: z 26 października 2001 r., Ts 72/01, OTK ZU 2001, nr 8, poz. 298; z 11 grudnia 2002 r. 17 marca 2003 r., Ts 116/02, OTK ZU 2003, nr 2, seria B, poz. 104 i 105; z 14 września 2004 r., Ts 74/04, OTK ZU 2004, nr 5, seria B, poz. 313; z 12 października 2004 r. i 23 lutego 2005 r., Ts 35/04, OTK ZU 2005, nr 1, seria B, poz. 25 i 26; z 3 października 2005 r., Ts 148/05, OTK ZU 2006, nr 1, seria B, poz. 70; z 21 kwietnia 2006 r., Ts 58/06, OTK ZU 2006, nr 3, seria B, poz. 126; z 9 października 2007 r. i 16 grudnia 2008 r., Ts 71/07, OTK ZU 2008, nr 6, seria B, poz. 225 i 226; z 11 stycznia 2010 r., Ts 50/08, OTK ZU 2010, nr 1, seria B, poz. 14; z 8 lipca 2011 r., Ts 145/11, OTK ZU 2011, nr 4, seria B, poz. 339; z 15 września 2011 r. i 14 grudnia 2011 r., Ts 186/10, OTK ZU 2011, nr 6, seria B, poz. 445 i 446; z 9 listopada 2011 r. i 11 lipca 2012 r., Ts 171/10, OTK ZU 2012, nr 4, seria B, poz. 342 i 343; z 14 grudnia 2011 r. i 28 listopada 2014 r., Ts 110/11, OTK ZU 2014, nr 6, seria B, poz. 529 i 530; z 29 marca 2012 r., Ts 13/12, niepubl.; z 8 maja 2012 r., Ts 82/10, OTK ZU 2012, nr 3, seria B, poz. 269; z 12 grudnia 2013 r. i 29 lipca 2014 r., Ts 156/12, OTK ZU 2014, nr 4, seria B, poz. 271 i 272; z 8 grudnia 2014 r., Ts 291/14, OTK ZU 2014, nr 6, poz. 639; z 11 lutego 2015 r., Ts 187/14, niepubl.; z 18 marca 2015 r., Ts 257/14, niepubl.; z 19 maja 2015 r., Ts 317/13, niepubl.; z 16 czerwca 2015 r., Ts 169/15, niepubl.; zob. także wyrok TK z 18 września 2014 r., K 44/12, OTK ZU 2014, nr 8, seria A, poz. 92. 
z wolności i praw konstytucyjnych, których celem jest określenie statusu jednostki w relacjach z organami władzy publicznej i ochrona jednostki przed nadmierną ingerencją tych podmiotów. Po drugie, skarga konstytucyjna jest środkiem ochrony praw jednostki przed działaniem władzy publicznej i nie może służyć rozstrzyganiu sporów między poszczególnymi organami tej władzy. Po trzecie, jednostki samorządu terytorialnego mają zagwarantowany w Konstytucji inny instrument inicjowania kontroli konstytucyjności aktów normatywnych - wniosek (art. 191 ust. 1 pkt 3).

Jednak Trybunał2 oraz przedstawiciele doktryny ${ }^{3}$ nie w każdym przypadku wykluczają dopuszczalność wniesienia skargi konstytucyjnej przez podmioty prawa publicznego. W jednym $\mathrm{z}$ ostatnich orzeczeń TK stwierdził: „treść art. 79 ust. 1 Konstytucji nie daje podstaw do apriorycznego wyłączenia legitymacji skargowej; w świetle tego przepisu punkt ciężkości oceny powinien być przesunięty z badania cech podmiotu skarżącego na badanie, czy przysługują mu konstytucyjne wolności lub prawa. (...) przyjęcie, że danemu podmiotowi przysługuje konstytucyjne prawo lub wolność, implikuje bowiem uznanie, iż ma on legitymację czynną do wniesienia skargi konstytucyjnej”" . Legitymację skargową podmiotów publicznych zawęża się jednak do sytuacji, gdy występują one w sferze prawa prywatnego jako adresat konstytucyjnych wolności i praw 5 .

Należy zwrócić uwagę, że również w systemach prawnych innych państw europejskich jednostki samorządu terytorialnego generalnie nie są legitymowane do wnoszenia skarg konstytucyjnych ${ }^{6}$. Przykładowo, Ustawa Zasadnicza RFN wprawdzie odnosi prawa podstawowe także do

2 Zob. m.in. wyroki TK: z 3 lutego 2005 r., SK 7/03, OTK ZU 2005, nr 4, seria A, poz. 34; z 21 marca 2005 r., SK 24/04, OTK ZU 2005, nr 3, seria A, poz. 25; postanowienie TK z 29 marca 2012 r., Ts 13/12, niepubl.

3 Zob. B. Banaszak, Skarga konstytucyjna i jej znaczenie w zakresie ochrony praw podstawowych, [w:] Podstawowe prawa jednostki i ich sqqdowa ochrona, red. L. Wiśniewski, Warszawa 1997, s. 178; P. Tuleja, M. Grzybowski, Skarga konstytucyjna jako środek ochrony praw jednostki w polskim systemie prawa, [w:] Sądy i trybunały w Konstytucji i w praktyce, red. W. Skrzydło, Warszawa 2005, s. 108-109.

4 Postanowienie TK z 18 grudnia 2013 r., Ts 13/12, niepubl.

5 Szerzej zob. A. Kustra, Legitymacja podmiotów publicznych do wniesienia skargi konstytucyjnej, „Zagadnienia Sądownictwa Konstytucyjnego” 2011, nr 2, s. 87 i n.; A. Krzywoń, Zdolność skargowa publicznych podmiotów gospodarczych w postępowaniu przed Trybunatem Konstytucyjnym, „Państwo i Prawo” 2014, z. 11, s. 19 i n. Zob. także wyroki TK: z 3 lutego 2005 r., SK 7/03, OTK ZU 2005, nr 4, seria A, poz. 34; z 21 marca 2005 r., SK 24/04, OTK ZU 2005, nr 3, seria A, poz. 25; postanowienie TK z 29 marca 2012 r., Ts 13/12, niepubl.

6 Szerzej zob. J. Jagoda, Sądowa ochrona samodzielności jednostek samorzq̨du terytorialnego, Warszawa 2011, s. 337 i n. oraz cyt. tam lit. i orzecznictwo. 
krajowych osób prawnych (art. 19 ust. 3), pod warunkiem że znajdują do nich zastosowanie, ale Federalny Sąd Konstytucyjny (Bundesverfassungsgericht) odmawia osobom prawnym prawa publicznego prawa do wniesienia skargi konstytucyjnej, jako że skarga nie może służyć jako mechanizm rozstrzygania sporów między organami publicznymi ${ }^{7}$. Nie widzi jednak przeszkód, by podmioty te korzystały ze skargi konstytucyjnej w razie naruszenia tzw. praw sądowych ${ }^{8}$. Należy również podkreślić, że niemiecka Ustawa Zasadnicza w art. 93 ust. 1 pkt $4 \mathrm{~b}$ przyznaje jednostkom samorządu terytorialnego (gminom i związkom gmin) prawo do tzw. komunalnej skargi konstytucyjnej (kommunale Verfassungsbeschwerde).

W Polsce nie przewidziano takiego rozwiązania, mimo że w rozdziale VII Konstytucji przyznano jednostkom samorządu terytorialnego określone prawa podmiotowe, które powinny podlegać ochronie na poziomie konstytucyjnym. Dlatego też gminy szukają ochrony konstytucyjnej swych praw za pośrednictwem skargi konstytucyjnej. Nie ma natomiast jasności, czy gminy mogą być objęte zakresem pojęcia „każdy, czyje konstytucyjne wolności i prawa zostały naruszone" $\mathrm{z}$ art. 79 ust. 1 Konstytucji, a więc czy skarga służy ochronie wyłącznie praw uregulowanych $\mathrm{w}$ rozdziale II (ewentualnie w rozdziale I).

\section{Zakres podmiotowy skargi konstytucyjnej w kontekście legitymacji skargowej gminy}

$\mathrm{Z}$ art. 79 ust. 1 wynika, że uprawnienie do złożenia skargi konstytucyjnej przysługuje każdemu, czyje konstytucyjne wolności lub prawa zostały naruszone. Użyty w art. 79 ust. 1 zwrot „każdy” może prima facie sugerować, że krąg podmiotów uprawnionych do wniesienia skargi konstytucyjnej jest bardzo szeroki, wręcz nieograniczony. Jednak umiejscowienie tego przepisu w rozdziale II Konstytucji, odnoszącym się do wolności i praw człowieka i obywatela, wyklucza traktowanie skargi jako powszechnego środka ochrony (actio popularis) ${ }^{10}$. Zwrot „każdy” oznacza zatem tego, kto jest podmiotem konstytucyjnych wolności i praw

7 Orzeczenie Bundesverfassungsgericht z 25 marca 1981 r., BverfGE 57, 1 (9); zob. M. Derlatka, Skarga konstytucyjna w Niemczech, Warszawa 2009, s. 96 i n.; J. Jagoda, Saqdowa..., s. 337 i n. oraz cyt. tam lit.

8 Orzeczenie Bundesverfassungsgericht z 8 lipca 1982 r., BverfGE 61, 82 (104).

9 Szerzej zob. m.in. J. Jagoda, Sqdowa..., s. 358 i n.

10 Zob. m.in. postanowienie TK z 8 lipca 2011 r., Ts 145/11, OTK ZU 2011, nr 4, seria B, poz. 339. 
podmiotowych ${ }^{11}$, które $\mathrm{w}$ konkretnym przypadku zostały naruszone przez prawodawcę.

Jak wynika z orzecznictwa TK, decydujące znaczenie dla ustalenia kręgu podmiotów uprawnionych do złożenia skargi konstytucyjnej mają: a) funkcja skargi konstytucyjnej jako środka ochrony konstytucyjnych wolności i praw, przede wszystkim człowieka i obywatela; b) status (charakter) prawny danego podmiotu w znaczeniu zdolności bycia podmiotem wolności i praw konstytucyjnych chronionych za pomocą skargi konstytucyjnej; c) zakres podmiotowych praw i wolności konstytucyjnych przysługujących innym niż osoby fizyczne podmiotom prawa ${ }^{12}$. O zakresie podmiotowym skargi, a tym samym konstytucyjnych wolności i praw, nie przesądza natomiast wyposażenie danego podmiotu w oso-

11 Nie ma wątpliwości, że podmiotami konstytucyjnych wolności i praw uprawnionymi do wystąpienia ze skargą konstytucyjną są osoby fizyczne (człowiek lub obywatel w zależności od zakresu podmiotowego danego prawa). W doktrynie i orzecznictwie TK przyjmuje się także, że skargę złożyć mogą osoby prawne, ale wyłącznie w takim zakresie, w jakim powołują się na ochronę przysługujących im praw stanowiących emanację podmiotowych praw i wolności jednostki chronionych na poziomie konstytucyjnym (np. wolności działalności gospodarczej, wolności zrzeszania się, prawa do ochrony własności). Z uprawnienia tego mogą korzystać osoby prawne prawa prywatnego (np. związki wyznaniowe, stowarzyszenia, spółki) - zob. J. Trzciński, Zakres podmiotowy i podstawa skargi konstytucyjnej, [w:] Skarga konstytucyjna, red. J. Trzciński, Warszawa 2000, s. 49 i n.; Z. Czeszejko-Sochacki, L. Garlicki, J. Trzciński, Komentarz do ustawy o Trybunale Konstytucyjnym, Warszawa 1999, s. 157; B. Szmulik, Skarga konstytucyjna. Polski model na tle porównawczym, Warszawa 2006, s. 42; M. Wyrzykowski, M. Ziółkowski, Konstytucyjny status proceduralny jednostki jako adresata działań organów administracji, [w:] Konstytucyjne podstawy funkcjonowania administracji publicznej, red. R. Hauser, Z. Niewiadomski, A. Wróbel, Warszawa 2012, s. 306-307; zob. także J. Jagoda, Sqqdowa..., s. 335 i n.; wyrok TK z 8 czerwca 1999 r., SK 12/98, OTK ZU 1999, nr 5, poz. 96; postanowienia TK: z 21 marca 2000 r., SK 6/99, OTK ZU 2000, nr 2, poz. 66; z 14 września 2004 r., Ts 74/04, OTK ZU 2004, nr 5, seria B, poz. 313; z 12 października 2004 r., Ts 35/04, OTK ZU 2004, nr 1, seria B, poz. 25 ; z 21 kwietnia 2006 r., Ts 58/06, OTK ZU 2006, nr 3, seria B, poz. 126; z 9 października 2007 r., Ts 71/07, OTK ZU 2008, nr 6, seria B, poz. 225; z 14 kwietnia 2014 r., Ts 317/13, niepubl. Nie wyklucza się też dopuszczalności wniesienia skargi przez partię polityczną, ale wyłącznie w sprawach, w których partia polityczna występuje jako podmiot prywatny na podstawie przepisów prawa powszechnie obowiązującego normujących położenie wszystkich podmiotów prawa (np. gdyby partia kwestionowała zgodność z Konstytucją przepisów cywilnego prawa rzeczowego, na podstawie których zostało wydane ostateczne rozstrzygnięcie naruszające jej prawo własności) - zob. postanowienia TK z 17 listopada 2010 r. i 15 września 2011 r., Ts 256/09, OTK ZU 2011, nr 5, seria B, poz. 358 i 359.

12 Zob. w szczególności postanowienie TK z 22 maja 2007 r., SK 70/05, OTK ZU 2007, nr 6, seria A, poz. 60; zob. także m.in. postanowienia TK: z 12 października 2004 r. i 23 lutego 2005 r., Ts 35/04, OTK ZU 2004, nr 1, seria B, poz. 25 i 26; z 12 grudnia 2013 r., Ts 156/12, OTK ZU 2014, nr 4, seria B, poz. 271. 
bowość prawną ${ }^{13}$, której brak nie jest przeszkodą do bycia podmiotem konstytucyjnych praw ${ }^{14}$.

W doktrynie już na początku funkcjonowania skargi konstytucyjnej w polskim systemie prawa przyjęto, że pojęcie „każdy” z art. 79 ust. 1 Konstytucji nie obejmuje organów władzy publicznej, w tym organów samorządu terytorialnego ${ }^{15}$. Przepisy konstytucyjne o wolnościach i prawach zostały skonstruowane na zasadzie korelacji uprawnień jednostki i obowiązków organów władzy publicznej - określają relacje jednostki wobec państwa oraz innych podmiotów władzy publicznej (większość wolności i praw przybiera $\mathrm{w}$ związku $\mathrm{z}$ tym postać publicznych praw podmiotowych). Celem tych przepisów oraz podstawową funkcją skargi konstytucyjnej jest ochrona jednostki przed nadmierną ingerencją organów władzy publicznej, które obowiązane są do zapewnienia jednostce realizacji przysługujących jej wolności i praw oraz korzystania z nich ${ }^{16}$. Organy władzy publicznej i inne podmioty realizujące zadania publiczne nie są adresatami uprawnień wynikających z poszczególnych wolności i praw konstytucyjnych i w związku z tym nie mogą korzystać ze skargi konstytucyjnej ${ }^{17}$. Uznanie, że są adresatami tych uprawnień, prowadziłoby do utożsamienia podmiotów ingerujących w konstytucyjne prawa podmiotowe $\mathrm{z}$ ich nosicielami ${ }^{18}$. Przyjmuje się zatem, że skarga konstytucyjna przysługuje podmiotom prywatnoprawnym $\mathrm{w}$ sytuacji, gdy ich prawa są naruszane przez działanie podmiotów prawa publicznego ${ }^{19}$. Funkcją skargi nie jest ochrona praw podmiotów publicznoprawnych ${ }^{20}$ i nie może

13 Zob. w szczególności postanowienie TK z 14 września 2004 r., Ts 74/04, OTK ZU 2004, nr 5, seria B, poz. 313.

14 Zob. w szczególności postanowienie TK z 23 lutego 2005 r., Ts 35/04, OTK ZU 2005, nr 1, seria B, poz. 26.

15 J. Trzciński, Zakres..., s. 53; J. Trzciński, Podmiotowy zakres skargi konstytucyjnej, [w:] Konstytucja. Wybory. Parlament. Studia ofiarowane Zdzisławowi Jaroszowi, red. L. Garlicki, Warszawa 2000, s. 213.

16 Zob. m.in. postanowienia TK: z 12 października 2004 r. i 23 lutego 2005 r., Ts 35/04, OTK ZU 2004, nr 1, seria B, poz. 25 i 26; z 22 maja 2007 r., SK 70/05, OTK ZU 2007, nr 6, seria A, poz. 60; zob. także wyrok TK z 18 września 2014 r., K 44/12, OTK ZU 2014, $\mathrm{nr}$ 8, seria A, poz. 92.

17 Zob. postanowienia TK: z 6 lutego 2001 r. i 3 kwietnia 2001 r., Ts 148/00, OTK ZU 2001, nr 3, poz. 72 i 73; z 26 października 2001 r., Ts 72/01, OTK ZU 2001, nr 8, poz. 298; z 11 grudnia 2002 r. i 17 marca 2003 r., Ts 116/02, OTK ZU 2003, nr 2, seria B, poz. 104 i 105; z 12 października 2004 r., Ts 35/04, OTK ZU 2005, nr 5, seria B, poz. 25; z 9 października 2007 r. i 16 grudnia 2008 r., Ts 71/07, OTK ZU 2008, nr 6, seria B, poz. 225 i 226.

18 Zob. postanowienie TK z 26 października 2001 r., Ts 72/01, OTK ZU 2001, nr 8, poz. 298.

19 Zob. postanowienie TK z 25 lipca 2002 r., Ts 67/02, OTK ZU 2002, nr 3, seria B, poz. 231.

20 Zob. postanowienie TK z 22 maja 2007 r., SK 70/05, OTK ZU 2007, nr 6, seria A, poz. 60. 
być ona środkiem służącym rozstrzyganiu sporów między podmiotami władzy publicznej ${ }^{21}$.

Status ustrojowo-prawny gminy uregulowany został poza rozdziałem II Konstytucji. Podstawowe znaczenie mają przepisy rozdziału VII oraz rozdziału I (art. 15 i 16). Wykładnia tych przepisów prowadzi do wniosku, że gmina jest podmiotem o złożonym charakterze ${ }^{22}$. Po pierwsze, jest podstawową jednostką zasadniczego podziału terytorialnego państwa (art. 164 ust. $1 \mathrm{w}$ zw. $\mathrm{z}$ art. 15), ale także wspólnotą samorządową, którą z mocy prawa tworzą jej mieszkańcy (art. 16 ust. 1). Po drugie, gmina - wykonując (de facto za pośrednictwem swoich organów) zadania samorządu terytorialnego, tj. zadania publiczne - może być uznana za podmiot władzy publicznej (art. 164 ust. $3 \mathrm{w}$ zw. $\mathrm{z}$ art. $163 \mathrm{i}$ art. 16 ust. 2), lecz jednocześnie ustawodawca konstytucyjny wyposażył jednostki samorządu terytorialnego w osobowość prawną, którą powiązał z prawem własności i innymi prawami majątkowymi (art. 165 ust. 1). Z kontekstu systemowego art. 165 ust. 1 Konstytucji wynika, że pojęcie „osobowość prawna” zostało użyte na oznaczenie zdolności jednostek samorządu terytorialnego do występowania w majątkowych stosunkach prawa cywilnego we własnym imieniu. Można wręcz uznać, że bezpośrednim zamiarem ustawodawcy konstytucyjnego było uregulowanie statusu gminy właśnie w sferze prawa prywatnego.

Osobowość prawna zagwarantowana gminie na poziomie Konstytucji ma charakter jednolity, zróżnicowana jest natomiast podmiotowość prawna tej jednostki. Gmina może bowiem działać - za pośrednictwem swoich organów - jako podmiot realizujący władztwo publiczne (sfera imperium) oraz jako podmiot prawa prywatnego wyposażony w prawo własności i inne prawa majątkowe (sfera dominium) ${ }^{23}$. Nie sposób jednak określić abstrakcyjnie granicy między działalnością gminy w obu tych sferach. Status podmiotowy, zasady ustroju i funkcjonowania oraz zakres uprawnień i zadań jednostek samorządu terytorialnego musi być uregulowany przepisami prawa. Można przyjąć, że działalność gminy $\mathrm{w}$ obu tych sferach powinna służyć realizacji interesu publicznego, a sfera cywilnoprawnej działalności gminy powinna być zdetermino-

21 Zob. postanowienia TK: z 11 grudnia 2002 r. i 17 marca 2003 r., Ts 116/02, OTK ZU 2003, nr 2, seria B, poz. 104 i 105; z 8 lipca 2011 r., Ts 145/11, OTK ZU 2011, nr 4, seria B, poz. 339.

22 W literaturze z zakresu prawa administracyjnego używa się określenia „wielopostaciowość" gminy - J. Dobkowski, Wielopostaciowość gminy w prawie polskim, [w:] Kryzys prawa administracyjnego?, t. 1, Jakość prawa administracyjnego, red. D.R. Kijowski, A. Miruć, A. Suławko-Karetko, Warszawa 2012, s. 253 i n.

23 Szerzej zob. A. Doliwa, Osobowość prawna jednostek samorzqdu terytorialnego, Warszawa 2012, s. 178 i n., 477 i n. oraz cyt. tam lit. 
wana podmiotowością tejże $\mathrm{w}$ sferze prawa publicznego ${ }^{24}$. Nie wydaje się jednak zasadne - co jest sporne zresztą w doktrynie - używanie względem jednostek samorządu terytorialnego określenia „osoby prawne prawa publicznego", zwłaszcza że Konstytucja nie posługuje się tym terminem ${ }^{25}$. Pojęcia tego używa TK, ale nie określa żadnego kryterium rozróżnienia osób prawnych prawa publicznego i osób prawnych prawa prywatnego ${ }^{26}$.

Co istotne, Konstytucja nie daje żadnych podstaw do uznania jednostek samorządu terytorialnego za organy władzy publicznej, co pozwoliłoby a priori wykluczyć możliwość występowania przez nie ze skargą konstytucyjną. $Z$ treści art. 163 wynika bowiem tylko tyle, że samorząd terytorialny wykonuje zadania publiczne niezastrzeżone prawem dla organów innych władz publicznych ${ }^{27}$. Gmina nie jest organem władzy publicznej (organem administracji). Zadania z zakresu administracji publicznej najczęściej nie są wykonywane przez gminę jako osobę prawną, lecz przez jej organy, które w sferze prawa publicznego nie działają w imieniu i na rachunek gminy, lecz na podstawie kompetencji przyznanych przez ustawy. Konieczne jest odróżnienie gminy od organu działającego w imieniu gminy - osoby prawnej oraz od organu gminy jako organu administracji publicznej. Zadania publiczne powierzone gminie realizuje de facto organ administracji publicznej w ramach określonych mu obowiązków.

Kluczowe znaczenie dla przyznania gminie legitymacji skargowej ma ustalenie, czy jest ona adresatem (bądź może być uznana za adresata) uprawnień wynikających z wolności lub praw konstytucyjnych. Legitymacja skargowa gminy zależy więc od rodzaju praw chronionych konstytucyjnie, które stawiają ją w sytuacji analogicznej do sytuacji osób fizycznych czy osób prawnych prawa prywatnego. Zastrzec jedynie należy, że posiadanie osobowości prawnej nie jest wystarczającą podstawą do utożsamiania zakresu konstytucyjnej ochrony jednostek samorządu terytorialnego z zakresem ochrony konstytucyjnej osób prawnych ${ }^{28}$. Poza tym, nawet korzystanie przez gminę $w$ ramach realizacji praw konstytucyjnych $\mathrm{z}$ form prawnych właściwych dla prawa prywatnego

24 A. Doliwa, Osobowość..., s. 470 i n. oraz cyt. tam lit.

25 Szerzej zob. A. Doliwa, Osobowość..., s. 200 i n. oraz cyt. tam lit. (w szczególności zob. P. Radziewicz, Kilka uwag w sprawie prawnej przydatności pojęcia „osoba prawa publicznego”, „Samorząd Terytorialny” 2000, nr 6, s. 3 i n.).

26 Zob. m.in. wyrok TK z 13 marca 2013 r., K 25/10, OTK ZU 2013, nr 3, seria A, poz. 27.

27 Por. M. Zubik, Orzekanie przez Trybunat Konstytucyjny o przepisie nieobowiq̨zującym dotyczącym jednostek samorzq̨du terytorialnego, „Państwo i Prawo” 2014, z. 1, s. 12 i n.

28 J. Stępień, Samorzq̨d terytorialny, [w:] Księga XX-lecia orzecznictwa Trybunału Konstytucyjnego, red. M. Zubik, Warszawa 2006, s. 624; zob. także postanowienie TK z 22 maja 2007 r., SK 70/05, OTK ZU 2007, nr 6, seria A, poz. 60. 
nie musi uzasadniać przyznania jej ochrony wynikającej ze skargi konstytucyjnej ${ }^{29}$.

Można natomiast zastanawiać się, czy uzasadnienia dla legitymacji gminy do złożenia skargi konstytucyjnej trzeba poszukiwać w jej korporacyjnym charakterze jako wspólnoty samorządowej. Trudno rozstrzygnąć na płaszczyźnie dogmatycznej, czy prawa gminy określone w Konstytucji mają część wspólną z prawami podmiotowymi obywateli będących członkami gminnej wspólnoty samorządowej oraz w jakim stopniu wolności i prawa konstytucyjne członków wspólnoty gminnej znajdują emanację w prawach tej jednostki samorządu, a także, czy prawa gminy stanowią odrębną kategorię praw własnych, czy sumę części składowych praw ogółu jej mieszkańców. Należy natomiast wykluczyć dopuszczalność wystąpienia przez gminę ze skargą konstytucyjną w celu ochrony praw podmiotowych członków gminnej wspólnoty samorządowej. Byłoby to sprzeczne z zasadą bezpośredniości skargi. Z art. 79 ust. 1 Konstytucji wynika bowiem wprost, że skargę może wnieść podmiot, którego wolności i prawa zostały naruszone ${ }^{30}$. Gmina ma charakter odmienny od osób prawnych tworzonych przez osoby fizyczne $\mathrm{w}$ ramach korzystania $\mathrm{z}$ konstytucyjnej wolności zrzeszania się w różnych celach społecznych, gospodarczych lub politycznych (art. 58). Po pierwsze, powstanie gminy nie jest skutkiem inicjatywy samorządowej (oddolnej), ale efektem decentralizacji władzy publicznej. Inny jest cel jej powstania i inne funkcje, jakie ma realizować. Po drugie, gmina jako osoba prawna jest podmiotem odrębnym od jej mieszkańców (członków gminnej wspólnoty samorządowej). Nie można uznać, że podmiotowość prawna gminy znajduje umocowanie w podstawowych prawach podmiotów tworzących wspólnotę samorządową, gdyż Konstytucja wyraźnie traktuje gminę jako odrębny podmiot prawa i wyposaża go w osobowość prawną ${ }^{31}$. Nieuzasadnione jest więc poszukiwanie podstaw legitymacji skargowej gminy przez odwołanie się do jej korporacyjnego charakteru.

29 Por. postanowienie TK z 18 marca 2010 r., Ts 163/09, OTK ZU 2010, nr 2, seria B, poz. 126.

30 Por. postanowienie TK z 18 marca 2010 r., Ts 163/09, OTK ZU 2010, nr 2, seria B, poz. 126 - wprawdzie orzeczenie dotyczyło legitymacji powiatu do wniesienia skargi konstytucyjnej w interesie członków wspólnoty samorządowej, to jednak wypływa z niego wniosek, że Trybunał odmawia jednostkom samorządu terytorialnego legitymacji do występowania ze skargą w celu ochrony praw podmiotowych ich mieszkańców.

31 M. Kruszewska-Gagoś, Podmiotowość publicznoprawna gminy, Lublin 2007, s. 30 . 


\section{Dopuszczalność ochrony skargowej praw podmiotowych gminy określonych w Konstytucji}

Na mocy przepisów zawartych w rozdziale VII Konstytucji gminie przysługują określone prawa podmiotowe. Są one w większości wysłowione explicite - prawo własności i prawa majątkowe (art. 165 ust. $1 \mathrm{zd}$. 2), prawo ustalania wysokości podatków i opłat lokalnych (art. 168), prawo zrzeszania się (art. 172 ust. 1) oraz prawo przystępowania do międzynarodowych zrzeszeń społeczności lokalnych i regionalnych oraz współpracy z takimi społecznościami innych państw (art. 172 ust. 2). Można też wywieść z tych przepisów prawo gminy do sądowej ochrony samodzielności (art. 165 ust. 2) oraz prawo do udziału w dochodach publicznych odpowiednio do przypadających jej zadań (art. 167 ust. 1). Skoro są to prawa konstytucyjne, to należy im się ochrona na poziomie konstytucyjnym.

Pozostają natomiast wątpliwości, czy prawa te mieszczą się w zakresie pojęcia „konstytucyjne wolności i prawa” z art. 79 ust. 1 Konstytucji. Jest ono wprawdzie rozumiane dość szeroko - przyjmuje się, że źródłem praw konstytucyjnych może być każdy przepis ustawy zasadniczej, z którego da się wywieść prawa podmiotowe kształtujące sytuację prawną jednostki - ale swoim zakresem obejmuje przede wszystkim wolności i prawa znajdujące podstawy w przepisach rozdziału II Konstytucji, co ma uzasadnienie systemowe i aksjologiczne ${ }^{32}$. Niewątpliwie jednak powiązanie praw jednostek samorządu terytorialnego z publicznoprawną sferą ich działania i wykonywaniem zadań publicznych nie pozwala objąć ich zakresem pojęcia „konstytucyjne wolności i prawa”33.

Ustawodawca konstytucyjny rzeczywiście umieścił skargę konstytucyjną w rozdziale II, który literalnie odnosi się do wolności i praw człowieka i obywatela. Przyporządkował ją do kategorii „środki ochrony wolności i praw", których już nie odniósł jednak ani wprost do wolności i praw z rozdziału II, ani wyłącznie do „człowieka i obywatela”. Oczywiście, systemowe powiązanie skargi konstytucyjnej z ochroną praw wyrażonych w rozdziale II nie jest bezzasadne. Nie można jednak wykluczyć i takiej interpretacji, że skarga to środek ochrony praw konstytucyjnych w ogóle, nie tylko tych znajdujących podstawy w rozdziale II Konstytucji.

32 Zob. Z. Czeszejko-Sochacki, L. Garlicki, J. Trzciński, Komentarz..., s. 158-159; J. Trzciński, Zakres..., s. 56; B. Szmulik, Skarga..., s. 85-110.

33 Zob. postanowienie TK z 12 października 2004 r., Ts 35/04, OTK ZU 2004, nr 1, seria B, poz. 25; por. P. Tuleja, Skarga konstytucyjna w Polsce - dziesięć lat doświadczeń, „Przegląd Legislacyjny” 2007, nr 3, s. 31. 
Odmienne są natomiast podstawy aksjologiczne omawianych kategorii praw konstytucyjnych. Źródłem praw jednostek samorządu terytorialnego jest bowiem decyzja ustawodawcy konstytucyjnego, a nie godność człowieka leżąca u podstaw wolności i praw człowieka i obywatela (art. 30 Konstytucji). W związku z tym praw gmin określonych w rozdziale VII nie można uznać za tożsame z prawami podmiotowymi z rozdziału II, choć wydają się równoległe i ekwiwalentne wobec niektórych praw zawartych w tym rozdziale. Należy tylko zastrzec, że nawet korzystanie przez gminę w ramach realizacji praw konstytucyjnych $\mathrm{z}$ form prawnych właściwych dla prawa prywatnego nie musi uzasadniać przyznania jej ochrony wynikającej ze skargi konstytucyjnej ${ }^{34}$. Charakter i treść danego prawa może jednak wymagać objęcia gmin ochroną skargową, zwłaszcza w kontekście zagwarantowanej w art. 165 ust. 2 Konstytucji ochrony sądowej samodzielności jednostek samorządu terytorialnego.

Przykładem praw konstytucyjnych gminy, które można uznać za równoległe i ekwiwalentne względem odpowiednich praw z rozdziału II Konstytucji, są prawo własności i inne prawa majątkowe (art. 165 ust. 1) oraz prawo do ochrony sądowej (art. 165 ust. 2).

Prawo własności (tak samo jak inne prawa majątkowe) zostało jednostkom samorządu terytorialnego zagwarantowane wprost w art. 165 ust. 1 zd. 2 Konstytucji ${ }^{35}$. Ustawodawca konstytucyjny odrębnie uregulował bowiem status gospodarczo-majątkowy tych jednostek w rozdziale poświęconym samorządowi terytorialnemu i jest to całkowicie uzasadnione. Konstytucyjna gwarancja własności gmin ma więc normatywną podstawę w art. 165, a nie w art. 64 ust. 1 Konstytucji ${ }^{36}$. Z kolei art. 167 tworzy formalną gwarancję wobec art. 165 Konstytucji $^{37}$. Nie ulega wątpliwości, że art. 165 ust. 1 stanowi normatywne źródło prawa podmiotowego gminy do własności, które powinno podlegać równej ochronie konstytucyjnej.

Trybunał wielokrotnie wypowiadał się w kwestii podmiotowości gminy w sferze własności, podkreślając szczególne znaczenie własności gminnej (komunalnej) i jej ochrony w systemie ustrojowym Rzeczypospolitej Polskiej ${ }^{38}$. W ujęciu rozdziału VII Konstytucji wyposażenie jednostek samorządu terytorialnego w majątek ma służyć zapewnieniu im

34 Por. postanowienie TK z 18 marca 2010 r., Ts 163/09, OTK ZU 2010, nr 2, seria B, poz. 126.

35 Zob. E. Łętowska, Własność i jej ochrona jako wzorzec kontroli konstytucyjności. Wybrane problemy, „Kwartalnik Prawa Prywatnego” 2009, z. 4, s. 896, 906.

36 Zob. m.in. wyrok TK z 20 lutego 2002 r., K 39/00, OTK ZU 2002, nr 1, seria A, poz. 4.

37 Zob. m.in. wyrok TK z 28 lutego 2008 r., K 43/07, OTK ZU 2008, nr 1, seria A, poz. 8.

38 Zob. w szczególności wyroki TK: z 12 kwietnia 2000 r., K 8/98, OTK ZU 2000, nr 3, poz. 87; z 20 lutego 2002 r., K 39/00, OTK ZU 2001, nr 1, seria A, poz. 4; zob. także postanowienie TK z 25 lipca 2002 r., Ts 67/02, OTK ZU 2002, nr 3, seria B, poz. 231. 
samodzielności, zabezpieczeniu ich podmiotowości prawnej oraz możliwości realizowania zadań publicznych o znaczeniu lokalnym, wyznaczonych przez ustawy. Jednocześnie art. 165 ust. 1 Konstytucji wyraźnie eksponuje ścisłą więź prawa własności jednostki samorządu terytorialnego $\mathrm{z}$ jej podmiotowością, co ma istotne znaczenie z punktu widzenia ochrony własności.

W wyroku z 13 marca 2013 r. ${ }^{39}$ TK w odniesieniu do stosunków własnościowych stwierdził jednak, że gminy nie są podmiotami konstytucyjnych wolności i praw. Potwierdza to, że Trybunał konsekwentnie traktuje jednostki samorządu terytorialnego jako osoby prawne prawa publicznego o szczególnym statusie, wyposażone we władztwo publiczne. Jednocześnie na tej podstawie, że gmina realizuje zadania publiczne, sąd konstytucyjny uznaje, iż art. 165 Konstytucji nie ustanawia na rzecz gmin konstytucyjnego prawa podmiotowego. $\mathrm{Z}$ tym stanowiskiem trudno się zgodzić ${ }^{40}$, gdyż - jak się wydaje - wyposażenie gmin w osobowość prawną było celowym zamierzeniem ustrojodawcy, by uczynić gminę równoprawnym podmiotem własności i innych praw majątkowych, wyodrębnić mienie gminne i podkreślić odrębność organizacyjną gmin od państwa. Przyznanie gminom osobowości prawnej służy głównie celom obrotu prawnego $\mathrm{w}$ sferze stosunków majątkowych, a nie zapewnieniu wykonywania władzy publicznej.

Należy zwrócić uwagę, że Konstytucja gwarantuje własność każdemu - osobom fizycznym i prawnym oraz jednostkom samorządu terytorialnego, tyle że na odrębnych podstawach normatywnych (odpowiednio art. 64 ust. 1 i art. 165 ust. 1$)^{41}$. Nie różnicuje jednocześnie form i typów własności ${ }^{42}$. Można uznać, że konstytucyjna gwarancja własności ma charakter uniwersalny w aspekcie podmiotowym. Na poziomie konstytucyjnym również ochrona własności nie jest zróżnicowana ze względu na podmiot prawa własności. Przepis art. 21 ust. 1 stanowi wprost, że państwo chroni własność (konstytucyjna zasada ochrony własności). Przyjmuje się nawet, że cechą każdej własności jest możliwość jej ochrony na drodze sądowej ${ }^{43}$. Wydaje się także, że wynikająca $\mathrm{z}$ art. 64 ust. 2

39 K 25/10, OTK ZU 2013, nr 3, seria A, poz. 27.

40 Zob. zdanie odrębne sędziego TK A. Wróbla do wyroku TK z 13 marca 2013 r., K 25/10, OTK ZU 2013, nr 3, seria A, poz. 27.

41 Por. postanowienie TK z 23 lutego 2005 r., Ts 35/04, OTK ZU 2005, nr 1, seria B, poz. 26.

42 Na temat spornej kwestii wyodrębnienia w Konstytucji reżimu własności publicznej i własności prywatnej zob. m.in. B. Banaszkiewicz, Konstytucyjne prawo do własności, [w:] Konstytucyjne podstawy systemu prawa, red. M. Wyrzykowski, Warszawa 2001, s. 52; L. Garlicki, komentarz do art. 20, [w:] Konstytucja Rzeczypospolitej Polskiej. Komentarz, t. IV, red. L. Garlicki, Warszawa 2005, s. 9, 11-12.

43 E. Łętowska, Własność..., s. 889 i n. 
Konstytucji gwarancja równej dla wszystkich ochrony prawnej własności potwierdza tę tezę, traktując własność w ujęciu przedmiotowym. Zatem jednostki samorządu terytorialnego, którym przysługuje konstytucyjne prawo własności, powinny korzystać z ochrony na takim samym poziomie jak osoby fizyczne czy inne osoby prawne. Jednak w orzecznictwie nie rozstrzygnięto dotychczas, czy jednostki samorządu terytorialnego również mogą być uznane za adresata art. 64 Konstytucji ${ }^{44}$.

Trybunał zdaje się deklarować uniwersalizm podmiotowy ochrony własności. W wyroku z 20 lutego $2002 \mathrm{r}^{45}$ uznał, że ochrona własności gminy nie powinna być słabsza od ochrony własności prywatnej, a wcześniej w wyroku z 21 marca $2000 \mathrm{r}^{46}$ wykluczył pogląd, iż ochrona własności prywatnej mogłaby być słabsza niż ochrona majątku jednostek samorządu terytorialnego. Z drugiej strony Trybunał zwraca uwagę na odmienność funkcji własności prywatnej i własności jednostek samorządu terytorialnego ${ }^{47}$. Prezentuje również stanowisko, że Konstytucja jednak różnicuje zakres ochrony prawa własności osoby fizycznej lub osoby prawnej prawa prywatnego oraz ochrony prawa własności jednostki samorządu terytorialnego, jako że prawo własności tych jednostek jest ściśle związane z ich zadaniami publicznymi, których realizacji powinno służyć. Własność komunalna jest - zdaniem TK - przede wszystkim majątkowym zabezpieczeniem realizacji zadań publicznych jednostek samorządu terytorialnego, nie można jej traktować tak jak własności służącej tylko działalności gospodarczej, w kategoriach czysto cywilistycznych ${ }^{48}$. Trybunał wypowiadał się również na temat niejednorodności funkcji poszczególnych składników majątku gminy - wyodrębnił mienie publiczne służące zaspokajaniu potrzeb publicznych oraz mienie służące celom gospodarczym ${ }^{49}$. Nie można więc a priori wykluczyć poszukiwania przez gminy ochrony mienia przeznaczonego na cele gospodarcze w trybie skargi konstytucyjnej, gdyby doszło do jego naruszenia przez podmioty władzy publicznej, oczywiście pod warunkiem, że gmina mogłaby być traktowana podobnie jak podmioty prawa prywatnego.

44 Por. wyrok TK z 2 czerwca 1999 r., K 34/98, OTK ZU 1999, nr 5, poz. 94; postanowienie TK z 22 maja 2007 r., SK 70/05, OTK ZU 2007, nr 6, seria A, poz. 60; zob. także postanowienia TK z 15 września 2011 r. i 14 grudnia 2011 r., Ts 186/10, OTK ZU 2011, nr 6, seria B, poz. 446; z 9 listopada 2011 r. i 11 lipca 2012 r., Ts 171/10, OTK ZU 2012, nr 4, seria B, poz. 342 i 343.

45 K 39/00, OTK ZU 2000, nr 1, seria A, poz. 4.

46 K 14/99, OTK ZU 2000, nr 2, poz. 61.

47 Zob. m.in. wyrok TK z 30 października 2001 r., K 33/00, OTK ZU 2001, nr 7, poz. 217.

48 Zob. m.in. postanowienie TK z 18 marca 2010 r., Ts 163/09, OTK ZU 2010, nr 2, seria $B$, poz. 126.

49 Zob. wyrok TK z 12 kwietnia 2000 r., K 8/98, OTK ZU 2000, nr 3, poz. 87; postanowienie TK z 25 lipca 2002 r., Ts 67/02, OTK ZU 2002, nr 3, seria B, poz. 231. 
Prawo do sądowej ochrony samodzielności gmin znajduje podstawy w art. 165 ust. 2 Konstytucji ${ }^{50}$. Przepis ten ma podwójny charakter: $\mathrm{z}$ jednej strony ustanawia konstytucyjną zasadę ochrony samodzielności jednostek samorządu terytorialnego, z drugiej - można $\mathrm{z}$ niego wywieść prawo podmiotowe o charakterze sądowym. Prawo do sądowej ochrony samodzielności jednostek samorządu terytorialnego nie jest jednak tożsame $\mathrm{z}$ prawem do sądu $\mathrm{z}$ art. 45 ust. 1 Konstytucji ${ }^{51}$. Ujęte jest $\mathrm{w}$ ustawie zasadniczej $\mathrm{w}$ aspekcie przedmiotowym (ochronie podlega samodzielność jednostek samorządu) oraz funkcjonalnym (ochronę zapewniają sądy). Z kolei prawo do sądu stanowi wiązkę uprawnień i gwarancji dla jednostki ${ }^{52}$ i należy je odczytywać w powiązaniu z zakazem zamykania drogi sądowej dochodzenia naruszonych wolności lub praw (art. 77 ust. 2 Konstytucji). Ma ono charakter powszechny w aspekcie podmiotowym - przysługuje wszystkim podmiotom występującym w obrocie i poszukującym ochrony prawnej ${ }^{53}$. Konstytucja gwarantuje bowiem każdemu prawo do sprawiedliwego i jawnego rozpatrzenia sprawy bez nieuzasadnionej zwłoki przez właściwy, niezależny, bezstronny i niezawisły sąd. Wyjątkiem są podmioty działające jako organy władzy publicznej - prawo do sądu nie może bowiem służyć do rozstrzygania sporów między tymi organami ${ }^{54}$. Jednocześnie - w ujęciu systemowym - Konstytucja stwarza podstawy zasady prawa do sądu (art. 2, art. 45 ust. $1 \mathrm{w}$ zw. z art. 77 ust. 2$)^{55}$, co pozwala traktować prawo do sądu jako generalny instrument ochrony konstytucyjnej oraz gwarancję ładu prawnego i przestrzegania prawa przez wszystkich. Nie można więc apriorycznie wykluczyć dopuszczal-

50 M. Zubik, „Wolność” a „prawo” (pięć hipotez o stosowaniu pojęć konstytucyjnych dotyczacych praw człowieka), „Państwo i Prawo” 2015, z. 9, s. 9.

51 Zob. także wyrok TK z 29 października 2009 r., K 32/08, OTK ZU 2009, nr 9, seria A, poz. 139; postanowienie TK z 19 maja 2015 r., Ts 317/13, niepubl.

52 Na konstytucyjne prawo do sądu składają się cztery elementy: a) prawo dostępu do sądu, tj. uruchomienia postępowania przed niezależnym, bezstronnym i niezawistym sądem; b) prawo do odpowiednio uksztattowanej, zgodnej z wymogami sprawiedliwości i jawności procedury sądowej; c) prawo do wyroku sądowego, tj. uzyskania wiążącego rozstrzygnięcia sprawy przez sąd; d) prawo do odpowiedniego ukształtowania ustroju i pozycji organów rozpoznających spory - zob. wyrok TK z 27 maja 2008 r., SK 57/06, OTK ZU 2008, nr 4, seria A, poz. 63.

53 Z. Czeszejko-Sochacki, Prawo do sq̨du w świetle Konstytucji Rzeczypospolitej Polskiej, „Państwo i Prawo” 1997, z. 11-12, s. 92; H. Zięba-Załucka, Prawo do rzetelnego procesu sq̨dowego, [w:] W służbie dobru wspólnemu. Księga jubileuszowa dedykowana Profesorowi Januszowi Trzcińskiemu, red. R. Balicki, M. Masternak-Kubiak, Warszawa 2012, s. 535.

54 Zob. m.in. Z. Czeszejko-Sochacki, Prawo..., s. 74; J. Trzciński, Podmiotowy..., s. 213; postanowienie TK z 22 maja 2007 r., SK 70/05, OTK ZU 2007, nr 6, seria A, poz. 16.

55 Szerzej zob. A. Kubiak, Konstytucyjna zasada prawa do sądu w świetle orzecznictwa Trybunału Konstytucyjnego, Łódź 2006. 
ności korzystania przez gminę z konstytucyjnych gwarancji prawa do sądu $^{56}$.

Konstytucyjna gwarancja sądowej ochrony samodzielności jednostek samorządu terytorialnego z art. 165 ust. 2 Konstytucji wymaga, by sądy w sferze stosowania prawa, a TK przez kontrolę konstytucyjności prawa, ochronę tę urzeczywistniały w jak najszerszym zakresie ${ }^{57}$. Można nawet przyjąć, że wynikający z art. 165 ust. 2 zakres sądowej ochrony samodzielności jednostek samorządu terytorialnego nie ogranicza się do ochrony ich własności i innych praw majątkowych, jak mogłaby sugerować wykładnia systematyczna Konstytucji ${ }^{58}$. Wprawdzie nie wydaje się oczywiste, by jednostki samorządu terytorialnego były jednocześnie objęte gwarancjami prawa do sądu z art. 45 Konstytucji na identycznych zasadach jak wszystkie podmioty własności w rozumieniu art. 64 Konstytucji ${ }^{59}$, ale wykluczenie możliwości korzystania przez gminę z gwarancji prawa do sądu (np. w celu ochrony własności) oznaczałoby, że ochrona gmin jako podmiotów praw konstytucyjnych ma charakter deklaratoryjny. Skoro gminie przysługują prawa określone wprost w Konstytucji, to jako prawa konstytucyjne powinny podlegać ochronie, nawet jeśli prawa jednostek samorządu terytorialnego mają swoiste funkcje i cele.

Przychylam się do poglądu, że uprawnienie do wniesienia skargi konstytucyjnej można uznać za element prawa do sądu ${ }^{60}$. Skargę również można uznać za środek sądowej ochrony samodzielności jednostek samorządu terytorialnego ${ }^{61}$. Jeżeli Konstytucja przyznaje jednostkom samorządu terytorialnego określone prawa chronione konstytucyjnie, to należy im zagwarantować ochronę także w sferze

$56 \mathrm{Na}$ temat ochrony sądowej jednostek samorządu terytorialnego szerzej zob. J. Jagoda, Sadowa..., s. 127-132, 161-165, 244-247.

57 Zob. wyrok TK z 18 lutego 2003 r., K 24/02, OTK ZU 2003, nr 2, seria A, poz. 11.

58 Tak E. Łętowska - podaję za: M. Zubik, „Wolność”..., s. 9, przyp. 18.

59 Zob. M. Zubik, „Wolność”..., s. 9, przyp. 18.

60 Z. Czeszejko-Sochacki, Skarga konstytucyjna w prawie polskim, „Przegląd Sejmowy” 1998, nr 1, s. 40. Zob. m.in. Z. Czeszejko-Sochacki, Prawo..., s. 74; J. Trzciński, Podmiotowy..., s. 213; postanowienie TK z 22 maja 2007 r., SK 70/05, OTK ZU 2007, $\mathrm{nr} 6$, seria A, poz. 16.; Szerzej zob. A. Kubiak, Konstytucyjna zasada prawa do sądu w świetle orzecznictwa Trybunału Konstytucyjnego, Łódź 2006.

$\mathrm{Na}$ temat ochrony sądowej jednostek samorządu terytorialnego szerzej zob. J. Jagoda, Sqdowa..., s. 127-132, 161-165, 244-247; Zob. wyrok TK z 18 lutego 2003 r., K 24/02, OTK ZU 2003, nr 2, seria A, poz. 11; E. Łętowska - podaję za: M. Zubik, „Wolność”..., s. 9, przyp. 18.; Zob. M. Zubik, „Wolnośc”..., s. 9, przyp. 18.; Z. Czeszejko-Sochacki, Skarga konstytucyjna w prawie polskim, „Przegląd Sejmowy” 1998, nr 1; A. Krzywoń, Zdolność..., s. 35.

61 Tak m.in. A. Wiktorowska, Prawne determinanty samodzielności gminy. Zagadnienia administracyjnoprawne, Warszawa 2002, s. 240; M. Kruszewska-Gagoś, Podmiotowość publicznoprawna gminy, Lublin 2007, s. 116-117. 
proceduralnej ${ }^{62}$. Nie można więc wykluczać dopuszczalności korzystania przez te jednostki z gwarancji proceduralnych prawa do sądu. Zakres podmiotowy skargi konstytucyjnej w przypadku jednostek samorządu terytorialnego należy więc odczytywać analogicznie do zakresu podmiotowego uprawnień wynikających z art. 45 ust. 1 Konstytucji. Jeżeli zatem gmina, działająca jako osoba prawna w sferze stosunków cywilnoprawnych, znalazłaby się w takiej samej sytuacji, jak osoby fizyczne czy inne osoby prawne, to nie można jej zamykać drogi sądowej tylko dlatego, że celem powstania gminy jest realizacja zadań publicznych, nota bene realizowanych przez jej organy. Co więcej, gdyby gmina wystąpiła do sądu konstytucyjnego w celu ochrony swoich legitymowanych interesów niewiążących się z wykonywaniem funkcji władczych (np. interesów majątkowych), to powinna być traktowana na równi $z$ innymi podmiotami.

W praktyce Trybunał $\mathrm{z}$ reguły odmawia gminom legitymacji do wniesienia skargi konstytucyjnej w sytuacji pozbawienia ich na drodze sądowej właśnie ochrony własności ${ }^{63}$. Nie dokonuje nawet rozróżnienia, czy skarga dotyczy mienia przeznaczonego na cele publiczne czy gospodarcze ${ }^{64}$. Znamiennym przykładem jest kazus Gminy Supraśl w maju 2007 r. ${ }^{65}$ TK umorzył postępowanie wszczęte skargą Gminy Supraśl, do której wniesienia nie była ona uprawniona. Pozbawił więc gminę możliwości ochrony na drodze sądowej jej interesu majątkowego naruszonego przez roszczenia restytucyjne Polskiego Autokefalicznego Kościoła Prawosławnego. Merytoryczne rozstrzygnięcie tej sprawy pozwoliłoby wówczas na wypracowanie pewnego standardu, który mógłby znaleźć zastosowanie $\mathrm{w}$ tego typu sprawach ${ }^{66}$. Tymczasem niewłaściwy - zdaniem Trybunału - tryb wszczęcia postępowania zadecydował o odmowie ochrony konstytucyjnej przysługującego gminie prawa podmiotowego własności i to w sytuacji naruszenia prawa do sądu.

62 Zob. M. Wiącek, Formalne przesłanki skargi konstytucyjnej (w świetle orzecznictwa TK), „Państwo i Prawo” 2011, z. 9, s. 34.

63 Zob. E. Łętowska, Własność..., s. 906-909.

64 Zob. postanowienia TK: z 12 października 2004 r., Ts 35/04, OTK ZU 2004, seria B, nr 1, poz. 25; z 14 grudnia 2011 r., Ts 186/10, OTK ZU 2011, nr 6, seria B, poz. 446.

65 Postanowienie TK z 22 maja 2007 r., SK 70/05, OTK ZU 2007, nr 6, seria A, poz. 60.

66 Szerzej zob. E. Łętowska, [w:] E. Łętowska, K. Sobczak, Rzeźbienie państwa prawa. 20 lat później, Warszawa 2012, s. 60 i n. 


\section{Skarga konstytucyjna a wniosek jako środek ochrony konstytucyjnych praw i kompetencji gminy}

Utrwalony w orzecznictwie TK pogląd o braku zdolności skargowej gminy jest ściśle wiązany z jej legitymacją do wystąpienia z wnioskiem stosownie do art. 191 ust. 1 pkt 3 Konstytucji. Wniosek traktowany jest jako szczególny instrument umożliwiający wszczęcie kontroli konstytucyjności prawa w celu ochrony praw i kompetencji jednostek samorządu terytorialnego. Uprawnienie do wystąpienia z wnioskiem przysługuje organowi stanowiącemu jednostki samorządu terytorialnego. Wprowadzono natomiast ograniczenie przedmiotowe - we wniosku zakwestionować można wyłącznie akt normatywny dotyczący spraw objętych zakresem działania danego podmiotu (art. 191 ust. 2 Konstytucji $)^{67}$. Trybunał przyjmuje na podstawie art. 191, że dany podmiot może mieć legitymację albo do inicjowania kontroli abstrakcyjnej w drodze wniosku, albo do wniesienia skargi konstytucyjnej. Uznanie, że jednostki samorządu terytorialnego są dodatkowo upoważnione do występowania ze skargą konstytucyjną, prowadziłoby do zatarcia granic między art. 79 ust. 1 a art. 191 Konstytucji ${ }^{68}$.

Z kolei wykładnia językowa i wykładnia a rubrica art. 191 ust. 1 Konstytucji pozwalają twierdzić, że Konstytucja odrębnie odnosi się do legitymacji jednostek samorządu terytorialnego do wszczęcia postępowania przed TK (art. 191 ust. 1 pkt 3) oraz legitymacji podmiotów określonych w art. 79 Konstytucji (art. 191 ust. 1 pkt 6). Jest to - jak się wydaje - konsekwencją odmienności wolności i praw człowieka i obywatela określonych w rozdziale II od praw jednostek samorządu terytorialnego wysłowionych w rozdziale VII Konstytucji. Ponadto w art. 191 ust. 1

67 Zgodnie z utrwaloną linią orzeczniczą TK, art. 191 ust. 2 w zw. z art. 191 ust. 1 pkt 3-5 Konstytucji należy interpretować ściśle także w odniesieniu do pojęcia „spraw objętych zakresem działania danego podmiotu". Kwestionowany we wniosku akt normatywny musi być bezpośrednio związany z wyznaczonym konstytucyjnie lub ustawowo zakresem działania danego podmiotu. Legitymacja podmiotów określonych w art. 191 ust. 1 pkt 3-5 do zainicjowania kontroli abstrakcyjnej jest więc szczególna. Nie są one uprawnione do występowania z wnioskami w sprawach ogólnopaństwowych lub ogólnospołecznych; zob. m.in. postanowienia TK: $z 17$ listopada 2004 r., Tw 41/04, OTK ZU 2004, nr 5, seria B, poz. 274; z 24 maja 2005 r., Tw 38/04, OTK ZU 2005, nr 3, seria B, poz. 97; z 19 kwietnia i 28 listopada 2005 r., Tw 56/04, OTK ZU 2005, nr 6, seria B, poz. 206 i 207; z 15 września 2010 r., Tw 12/10, OTK ZU 2010, nr 5, seria B, poz. 316; z 2 grudnia 2010 r., Tw 7/10, OTK ZU 2010, nr 6, seria B, poz. 401.

68 Zob. m.in. postanowienie TK z 18 marca 2010 r., Ts 163/09, OTK ZU 2010, nr 2, seria $\mathrm{B}$, poz. 126. 
pkt 6 użyto sformułowania „podmioty określone w art. $79 \mathrm{w}$ zakresie w nim wskazanym", co sugeruje raczej kompetencję uniwersalną. Na tej podstawie nie można więc wykluczyć dopuszczalności wystąpienia gminy ze skargą konstytucyjną, jeżeli dojdzie do naruszenia przysługującego jej prawa konstytucyjnego, a ochrona tego prawa na poziomie konstytucyjnym nie jest zróżnicowana podmiotowo (jak np. w przypadku prawa własności $\left.{ }^{69}\right)$.

Należy też zwrócić uwagę, że użyte art. 191 ust. 2 Konstytucji pojęcie "sprawy objęte zakresem działania” określające ramy przedmiotowe wniosku jest $\mathrm{w}$ orzecznictwie TK rozumiane wąsko - odnosi się je do spraw objętych zakresem działania i pozostających w związku z kompetencjami bezpośredniego wnioskodawcy, a więc organu stanowiącego ${ }^{70}$. Musi to być jednocześnie sprawa o charakterze publicznym (dotycząca interesu ogólnego), która pozwala utożsamić cel wystąpienia z wnioskiem $\mathrm{z}$ istotnymi cechami (kompetencjami) podmiotu legitymowanego do zainicjowania abstrakcyjnej kontroli prawa ${ }^{71}$. Można więc uznać, że ochrona samodzielności jednostek samorządu terytorialnego przez Trybunał jest niepełna ${ }^{72}$. Korzystając z wniosku, gmina może zainicjować kontrolę norm określających podstawy i zakres jej działania. Nie jest to jednak środek ochrony, z którego mogłaby skorzystać w razie bezpośredniego naruszenia jej praw podmiotowych. Poza tym nie wszystkie przepisy Konstytucji będą adekwatnymi wzorcami kontroli zainicjowanej wnioskiem organu stanowiącego jednostki samorządu terytorialnego. Trybunał wyklucza możliwość wystąpienia organu stanowiącego jednostki samorządu terytorialnego $\mathrm{z}$ wnioskiem o hierarchiczną kontrolę norm, jeżeli stawiane zarzuty wskazują na naruszenie przepisów Konstytucji, które mają charakter gwarancyjny w stosunku do obywateli (np. art. 32, art. 68 ust. 1 i 2 , art. 70$)^{73}$. Za adekwatne wzorce kontroli uznaje natomiast przepisy zawarte w rozdziale VII (art. 165 i 167) ${ }^{74}$ oraz w rozdziale I Konstytucji (np. art. 2, 7, 21) $)^{75}$.

69 Zob. zdanie odrębne sędzi TK E. Łętowskiej do postanowienia TK z 22 maja 2007 r., SK 70/05, OTK ZU 2007, nr 6, seria A, poz. 60.

70 Zob. w szczególności postanowienie TK z 8 lipca 2008 r., K 40/06, OTK ZU 2008, nr 6, seria A, poz. 113 oraz cyt. tam orzecznictwo.

71 Zob. postanowienie TK z 20 listopada 2001 r., K 28/00, OTK ZU 2001, nr 8, poz. 263.

72 Zob. m.in. J. Jagoda, Sqqdowa..., s. 322 i n.

73 Zob. postanowienie TK z 2 grudnia 2010 r., Tw 7/10, OTK ZU 2010, nr 6, seria B, poz. 401; por. postanowienie TK z 9 października 2002 r., Tw 33/02, OTK ZU 2002, nr 4, seria B, poz. 233.

74 Zob. np. wyroki TK: z 9 grudnia 2008 r., K 61/07, OTK ZU 2008, nr 10, seria A, poz. 174; z 12 października 2004 r., K 31/02, OTK ZU 2004, nr 9, seria A, poz. 91.

75 Zob. np. wyroki TK: z 9 grudnia 2008 r., K 61/07, OTK ZU 2008, nr 10, seria A, poz. 174; z 5 czerwca 2001 r., K 18/00, OTK ZU 2001, nr 5, poz. 118. 
Przyjmując nawet, że stosownie do art. 191 Konstytucji uprawnienia do wnoszenia skarg konstytucyjnych i wniosków nie powinny się dublować i że w przypadku jednostek samorządu terytorialnego zakres przedmiotowy kontroli zainicjowanej tymi środkami można uznać za tożsa$\mathrm{my}^{76}$, nie można zapominać o podstawowej różnicy między tymi dwoma instrumentami. Podstawową funkcją skargi jest bowiem ochrona konstytucyjnych praw podmiotowych, naruszonych w procesie stosowania zaskarżonego aktu normatywnego, natomiast celem wniosku jest zainicjowanie kontroli norm prawnych in abstracto (choć w przypadku jednostek samorządu terytorialnego zawężonej przedmiotowo), uzasadnione względami ochrony konstytucyjności i pewności prawa. Można zgodzić się, że dopuszczalność równoległego korzystania przez organy samorządu terytorialnego z instytucji wniosku i skargi konstytucyjnej w celu ochrony swego publicznoprawnego statusu podważałaby ratio legis instytucji skargi ${ }^{77}$. Gdyby jednak doszło np. do naruszenia własności gminy, to - przy założeniu uniwersalizmu konstytucyjnej gwarancji równości - aprioryczne wykluczenie dopuszczalności wniesienia przez nią skargi konstytucyjnej oznacza zaprzeczenie równości ochrony, jaką Konstytucja zapewnia wszystkim korzystającym z gwarancji własności ${ }^{78}$.

\section{Podsumowanie}

Założeniem Konstytucji jest efektywna ochrona wszystkich podmiotów objętych zakresem jej regulacji. Gmina jest podmiotem o szczególnym statusie, ale w ujęciu art. 165 jest przede wszystkim osobą prawną - podmiotem mającym zdolność prawną do uczestniczenia w obrocie na równych zasadach $\mathrm{z}$ innymi podmiotami prawa. Skoro gminie przysługują konkretne prawa konstytucyjne (jak np. prawo własności), to już na poziomie ustawy zasadniczej powinna mieć zagwarantowaną ochronę także w sferze proceduralnej. Wynika to choćby z konstytucyjnej gwarancji "sądowej ochrony samodzielności jednostek samorządu terytorialnego" (art. 165 ust. 2). Efektywność konstytucyjnej ochrony gmin zależy więc od tego, czy organy ją stosujące (sądy i sąd konstytucyjny) będą właściwie odczytywały intencje ustawodawcy konstytucyjnego, który - wbrew tezom prezentowanym w orzecznictwie TK - nie podporządkował dzia-

76 Por. A. Kustra, Legitymacja..., s. 90-91.

77 Zob. J. Trzciński, Podmiotowy..., s. 213; J. Trzciński, Zakres..., s. 53.

78 Zob. E. Łętowska, Własność..., s. 908-909. 
łalności jednostek samorządu terytorialnego wyłącznie realizacji zadań władzy publicznej. Nie można więc apriorycznie wykluczyć dopuszczalności korzystania przez gminę $\mathrm{z}$ proceduralnych gwarancji prawa do sądu, a także ze skargi konstytucyjnej w przypadku naruszenia jej praw podmiotowych, którym na poziomie konstytucyjnym należy się równa ochrona.

W praktyce TK każdorazowo (ad casum) musi ocenić, czy skarżąca gmina jest uprawniona do zainicjowania kontroli norm prawnych w trybie skargi konstytucyjnej ${ }^{79}$. Konieczne jest więc ustalenie, czy gmina jest podmiotem prawa, którego naruszenie zarzuca w skardze konstytucyjnej, oraz czy prawo to mieści się w zakresie pojęcia „konstytucyjne wolności i prawa" $\mathrm{z}$ art. 79 ust. 1 Konstytucji, będąc przynajmniej emanacją podmiotowych praw i wolności jednostki chronionych konstytucyjnie.

Należy przyznać, że w dotychczasowej praktyce TK uwzględniał przy ocenie legitymacji skarżących gmin stan faktyczny leżący u podstaw wniesienia poszczególnych skarg konstytucyjnych. W sprawach związanych $\mathrm{z}$ wykonywaniem przez gminę zadań władzy publicznej konsekwentnie odmawiał nadania dalszego biegu skardze konstytucyjnej ${ }^{80}$. Jeśli natomiast gmina zarzucała w skardze naruszenie praw wynikających z rozdziałów I i II Konstytucji, np. wolności prowadzenia działalności gospodarczej (art. $22 \mathrm{w}$ zw. z art. 20), prawa do sądu (art. 45), prawa własności (art. 64), prawa do wynagrodzenia szkody (art. 77), prawa do zaskarżania orzeczeń i decyzji (art. 78), TK żadnego z tych praw nie uznał za właściwą podstawę skargi konstytucyjnej gminy ${ }^{81}$. Trybunał wykluczył ponadto możliwość rozpatrzenia skargi konstytucyjnej opartej na zarzucie naruszenia konstytucyjnego prawa do sądowej ochrony samodzielności jednostek samorządu terytorialnego (art. 165 ust. 2) ${ }^{82}$, a także prawa do samodzielnego swobodnego wykonywania zadań publicznych (art. 16 ust. 2 i art. 166 ust. 1$)^{83}$. Podstawą skargi konstytucyjnej gminy nie może być również - zdaniem TK - zasada równości (art. 32) ${ }^{84}$.

79 Tak już Z. Czeszejko-Sochacki, Skarga..., s. 40-41.

80 Zob. m.in. postanowienia TK: z 8 grudnia 2014 r., Ts 291/14, OTK ZU 2014, nr 6, seria B, poz. 639; z 18 marca 2015 r., Ts 257/14, niepubl. - Trybunał odwołuje się w tych orzeczeniach do wcześniejszych postanowień o odmowie nadania biegu skardze konstytucyjnej z powodu braku legitymacji skargowej po stronie skarżącej gminy.

81 Zob. m.in. postanowienia TK: z 6 lutego 2001 r., Ts 148/00, OTK ZU 2001, nr 3, poz. 72; z 23 lutego 2005 r., Ts 35/04, OTK ZU 2005, nr 1, seria B, poz. 26.

82 Postanowienie TK z 23 lutego 2005 r., Ts 35/04, OTK ZU 2005, nr 1, seria B, poz. 26.

83 Postanowienie TK z 11 grudnia 2002 r., Ts 116/02, OTK ZU 2003, seria B, nr 2, poz. 104.

84 Zob. postanowienia TK: z 3 kwietnia 2001 r., Ts 148/00, OTK ZU 2001, nr 3, poz. 73; z 26 października 2001 r., Ts 72/01, OTK ZU 2001, nr 8, poz. 298; z 23 lutego 2005 r., Ts 35/04, OTK ZU 2005, seria B, nr 1, poz. 26. 
W doktrynie będą się zapewne nadal pojawiały głosy za przyznaniem i przeciw przyznaniu gminom legitymacji do wystąpienia ze skargą konstytucyjną. Nie można wykluczyć, że TK odstąpi od dotychczasowego poglądu prawnego o braku zdolności skargowej gminy, jeśli w konkretnym przypadku będzie tego wymagała potrzeba ochrony gminy przed naruszeniem istoty praw, które jej przynależą. Do rozważenia pozostaje wprowadzenie do polskiego systemu skargi komunalnej na wzór niemiecki, która służyłaby ochronie samodzielności i praw jednostek samorządu terytorialnego. Realizacja tego postulatu wymagałaby jednak zmiany Konstytucji.

\section{Bibliografia}

Banaszak B., Skarga konstytucyjna i jej znaczenie w zakresie ochrony praw podstawowych, [w:] Podstawowe prawajednostki i ich sq̨dowa ochrona, red. Wiśniewski L., Warszawa 1997.

Banaszkiewicz B., Konstytucyjne prawo do własności, [w:] Konstytucyjne podstawy systemu prawa, red. Wyrzykowski M., Warszawa 2001.

Czeszejko-Sochacki Z., Garlicki L., Trzciński J., Komentarz do ustawy o Trybunale Konstytucyjnym, Warszawa 1999.

Czeszejko-Sochacki Z., Prawo do sqadu w świetle Konstytucji Rzeczypospolitej Polskiej, „Państwo i Prawo” 1997, z. 11-12.

Czeszejko-Sochacki Z., Skarga konstytucyjna w prawie polskim, „Przegląd Sejmowy" 1998, nr 1.

Derlatka M., Skarga konstytucyjna w Niemczech, Warszawa 2009.

Dobkowski J., Wielopostaciowość gminy w prawie polskim, [w:] Kryzys prawa administracyjnego?, t. 1, Jakość prawa administracyjnego, red. Kijowski D.R., Miruć A., Suławko-Karetko A., Warszawa 2012.

Doliwa A., Osobowość prawna jednostek samorządu terytorialnego, Warszawa 2012.
Garlicki L., komentarz do art. 20, [w: Konstytucja Rzeczypospolitej Polskiej. Komentarz, t. IV, red. Garlicki L., Warszawa 2005.

Jagoda J., Sadowa ochrona samodzielności jednostek samorząu terytorialnego, Warszawa 2011.

Kruszewska-Gagoś M., Podmiotowość publicznoprawna gminy, Lublin 2007.

Krzywoń A., Zdolność skargowa publicznych podmiotów gospodarczych w postępowaniu przed Trybunatem Konstytucyjnym, „Państwo i Prawo” 2014, z. 11.

Kubiak A., Konstytucyjna zasada prawa do sadu w świetle orzecznictwa Trybunału Konstytucyjnego, Łódź 2006.

Kustra A., Legitymacja podmiotów publicznych do wniesienia skargi konstytucyjnej, „Zagadnienia Sądownictwa Konstytucyjnego" 2011, nr 2.

Łętowska E., [w:] E. Łętowska, K. Sobczak, Rzeźbienie państwa prawa. 20 lat później, Warszawa 2012.

Łętowska E., Własność i jej ochrona jako wzorzec kontroli konstytucyjności. Wybrane problemy, „Kwartalnik Prawa Prywatnego" 2009, z. 4.

Radziewicz P., Kilka uwag w sprawie prawnej przydatności pojęcia „osoba 
prawa publicznego”, „Samorząd Terytorialny" 2000, nr 6.

Stępień J., Samorzq̨d terytorialny, [w:] Księga XX-lecia orzecznictwa Trybunatu Konstytucyjnego, red. Zubik M., Warszawa 2006.

Szmulik B., Skarga konstytucyjna. Polski model na tle porównawczym, Warszawa 2006.

Trzciński J., Podmiotowy zakres skargi konstytucyjnej, [w:] Konstytucja. Wybory. Parlament. Studia ofiarowane Zdzisławowi Jaroszowi, red. Garlicki L., Warszawa 2000.

Trzciński J., Zakres podmiotowy i podstawa skargi konstytucyjnej, [w:] Skarga konstytucyjna, red. Trzciński J., Warszawa 2000.

Tuleja P., Skarga konstytucyjna w Polsce - dziesięć lat doświadczeń, „Przegląd Legislacyjny" 2007, nr 3.

Tuleja P., Grzybowski M., Skarga konstytucyjna jako środek ochrony praw jednostki w polskim systemie prawa, [w:] Sady i trybunaty w Konstytucji i w praktyce, red. Skrzydło W., Warszawa 2005.

Wiącek M., Formalne przesłanki skargi konstytucyjnej (w świetle orzecznictwa TK), „Państwo i Prawo” 2011, z. 9.
Wiktorowska A., Prawne determinanty samodzielności gminy. Zagadnienia administracyjnoprawne, Warszawa 2002.

Wyrzykowski M., Ziółkowski M., Konstytucyjny status proceduralny jednostki jako adresata działań organów administracji, [w:] Konstytucyjne podstawy funkcjonowania administracji publicznej, red. Hauser R., Niewiadomski Z., Wróbel A., Warszawa 2012.

Zięba-Załucka H., Prawo do rzetelnego procesu sądowego, [w:] Wsłużbie dobru wspólnemu. Księga jubileuszowa dedykowana Profesorowi Januszowi Trzcińskiemu, red. Balicki R., Masternak-Kubiak M., Warszawa 2012.

Zubik M., Orzekanie przez Trybunat Konstytucyjny o przepisie nieobowiqzujqcym dotyczącym jednostek samorzadu terytorialnego, „Państwo i Prawo” 2014, z. 1.

Zubik M., „Wolność” a „prawo” (pięć hipotez o stosowaniu pojęć konstytucyjnych dotyczacych praw człowieka), „Państwo i Prawo” 2015, z. 9.

\section{Orzecznictwo}

Wyrok TK z 18 września 2014 r., K 44/12, OTK ZU 2014, nr 8, seria A, poz. 92. Wyrok TK z 13 marca 2013 r., K 25/10, OTK ZU 2013, nr 3, seria A, poz. 27. Wyrok TK z 29 października 2009 r., K 32/08, OTK ZU 2009, nr 9, seria A, poz. 139. Wyrok TK z 9 grudnia 2008 r., K 61/07, OTK ZU 2008, nr 10, seria A, poz. 174. Wyrok TK z 27 maja 2008 r., SK 57/06, OTK ZU 2008, nr 4, seria A, poz. 63. Wyrok TK z 28 lutego 2008 r., K 43/07, OTK ZU 2008, nr 1, seria A, poz. 8. Wyrok TK z 21 marca 2005 r., SK 24/04, OTK ZU 2005, nr 3, seria A, poz. 25. Wyrok TK z 3 lutego 2005 r., SK 7/03, OTK ZU 2005, nr 4, seria A, poz. 34. Wyrok TK z 12 października 2004 r., K 31/02, OTK ZU 2004, nr 9, seria A, poz. 91. Wyrok TK z 18 lutego 2003 r., K 24/02, OTK ZU 2003, nr 2, seria A, poz. 11. Wyrok TK z 20 lutego 2002 r., K 39/00, OTK ZU 2002, nr 1, seria A, poz. 4. Wyrok TK z 30 października 2001 r., K 33/00, OTK ZU 2001, nr 7, poz. 217. Wyrok TK z 5 czerwca 2001 r., K 18/00, OTK ZU 2001, nr 5, poz. 118. Wyrok TK z 12 kwietnia 2000 r., K 8/98, OTK ZU 2000, nr 3, poz. 87. Wyrok TK z 21 marca 2000 r., K 14/99, OTK ZU 2000, nr 2, poz. 61. Wyrok TK z 8 czerwca 1999 r., SK 12/98, OTK ZU 1999, nr 5, poz. 96. 
Wyrok TK z 2 czerwca 1999 r., K 34/98, OTK ZU 1999, nr 5, poz. 94.

Postanowienie TK z 16 czerwca 2015 r., Ts 169/15, niepubl.

Postanowienie TK z 19 maja 2015 r., Ts 317/13, niepubl.

Postanowienie TK z 18 marca 2015 r., Ts 257/14, niepubl.

Postanowienie TK z 11 lutego 2015 r., Ts 187/14, niepubl.

Postanowienie TK z 8 grudnia 2014 r., Ts 291/14, OTK ZU 2014, nr 6, seria B, poz. 639.

Postanowienie TK z 28 listopada 2014 r., Ts 110/11, OTK ZU 2014, nr 6, seria B, poz. 530.

Postanowienie TK z 29 lipca 2014 r., Ts 156/12, OTK ZU 2014, nr 4, seria B, poz. 272.

Postanowienie TK z 14 kwietnia 2014 r., Ts 317/13, niepubl.

Postanowienie TK z 12 grudnia 2013 r., Ts 156/12, OTK ZU 2014, nr 4, seria B, poz. 271.

Postanowienie TK z 11 lipca 2012 r., Ts 171/10, OTK ZU 2012, nr 4, seria B, poz. i 343.

Postanowienie TK z 8 maja 2012 r., Ts 82/10, OTK ZU 2012, nr 3, seria B, poz. 269.

Postanowienie TK z 29 marca 2012 r., Ts 13/12, niepubl.

Postanowienie TK z 14 grudnia 2011 r., Ts 110/11, OTK ZU 2014, nr 6, seria B, poz. 529.

Postanowienie TK z 14 grudnia 2011 r., Ts 186/10, OTK ZU 2011, nr 6, seria B, poz. 446.

Postanowienie TK z 9 listopada 2011 r., Ts 171/10, OTK ZU 2012, nr 4, seria B, poz. 342.

Postanowienie TK z 15 września 2011 r., Ts 186/10, OTK ZU 2011, nr 6, seria B, poz. 445.

Postanowienie TK z 15 września 2011 r., Ts 256/09, OTK ZU 2011, nr 5, seria B, poz. 359.

Postanowienie TK z 8 lipca 2011 r., Ts 145/11, OTK ZU 2011, nr 4, seria B, poz. 339.

Postanowienie TK z 2 grudnia 2010 r., Tw 7/10, OTK ZU 2010, nr 6, seria B, poz. 401.

Postanowienie TK z 17 listopada 2010 r., Ts 256/09, OTK ZU 2011, nr 5, seria B, poz. 358.

Postanowienie TK z 15 września 2010 r., Tw 12/10, OTK ZU 2010, nr 5, seria B, poz. 316.

Postanowienie TK z 18 marca 2010 r., Ts 163/09, OTK ZU 2010, nr 2, seria B, poz. 126.

Postanowienie TK z 11 stycznia 2010 r., Ts 50/08, OTK ZU 2010, nr 1, seria B, poz. 14.

Postanowienie TK z 16 grudnia 2008 r., Ts 71/07, OTK ZU 2008, nr 6, seria B, poz. 226.

Postanowienie TK z 8 lipca 2008 r., K 40/06, OTK ZU 2008, nr 6, seria A, poz. 113.

Postanowienie TK z 9 października 2007 r., Ts 71/07, OTK ZU 2008, nr 6, seria B, poz. 225.

Postanowienie TK z 22 maja 2007 r., SK 70/05, OTK ZU 2007, nr 6, seria A, poz. 60.

Postanowienie TK z 21 kwietnia 2006 r., Ts 58/06, OTK ZU 2006, nr 3, seria B, poz. 126.

Postanowienie TK z 28 listopada 2005 r., Tw 56/04, OTK ZU 2005, nr 6, seria B, poz. 207.

Postanowienie TK z 3 października 2005 r., Ts 148/05, OTK ZU 2006, nr 1, seria B, poz. 70.

Postanowienie TK z 24 maja 2005 r., Tw 38/04, OTK ZU 2005, nr 3, seria B, poz. 97.

Postanowienie TK z 19 kwietnia 2005 r., Tw 56/04, OTK ZU 2005, nr 6, seria B, poz. 206.

Postanowienie TK z 23 lutego 2005 r., Ts 35/04, OTK ZU 2005, nr 1, seria B, poz. 26.

Postanowienie TK z 17 listopada 2004 r., Tw 41/04, OTK ZU 2004, nr 5, seria B, poz. 274.

Postanowienie TK z 12 października 2004 r., Ts 35/04, OTK ZU 2004, nr 1, seria B, poz. 25.

Postanowienie TK z 14 września 2004 r., Ts 74/04, OTK ZU 2004, nr 5, seria B, poz. 313.

Postanowienie TK z 17 marca 2003 r., Ts 116/02, OTK ZU 2003, nr 2, seria B, poz. 105.

Postanowienie TK z 11 grudnia 2002 r., Ts 116/02, OTK ZU 2003, nr 2, seria B, poz. 104.

Postanowienie TK z 9 października 2002 r., Tw 33/02, OTK ZU 2002, nr 4, seria B, poz. 233.

Postanowienie TK z 25 lipca 2002 r., Ts 67/02, OTK ZU 2002, nr 3, seria B, poz. 231.

Postanowienie TK z 20 listopada 2001 r., K 28/00, OTK ZU 2001, nr 8, poz. 263.

Postanowienie TK z 26 października 2001 r., Ts 72/01, OTK ZU 2001, nr 8, poz. 298.

Postanowienie TK z 3 kwietnia 2001 r., Ts 148/00, OTK ZU 2001, nr 3, poz. 73.

Postanowienie TK z 6 lutego 2001 r., Ts 148/00, OTK ZU 2001, nr 3, poz. 72.

Postanowienie TK z 21 marca 2000 r., SK 6/99, OTK ZU 2000, nr 2, poz. 66.

Orzeczenie Bundesverfassungsgericht z 8 lipca 1982 r., BverfGE 61, 82 (104).

Orzeczenie Bundesverfassungsgericht z 25 marca 1981 r., BverfGE 57, 1 (9). 